\title{
Design of Pre Blasting (Pre-Splitting) in Tan Cang Quarry NO.1 in Vietnam
}

\section{NGUYEN Dinh An ${ }^{1, *}$, PHAM Thai Hop ${ }^{2)}$, LE Cong Dien ${ }^{3)}$, TRAN Quang Hieu ${ }^{1)}$, TRAN Dinh Bao ${ }^{1)}$}

\footnotetext{
${ }^{1)}$ Hanoi University of Mining and Geology, Hanoi, Vietnam; email: nguyendinhan@humg.edu.vn; tranquanhieu@humg.edu.vn; trandinhbao@humg.edu.vn

2) Bien Hoa Building Materials Production and Construction Company, Dong Nai, Vietnam; email: hop.bbcc@gmail.com

3) Nam Bo Mining Chemical Industry Company - MICCO, Baria - Vungtau, Vietnam; email: dien.lc@micconambo.com

http://doi.org/10.29227/IM-2020-02-20
}

Submission date: 06-03-2020 | Review date: 22-09-2020

\section{Abstract}

Nowadays, construction material quarries in Dong Nai Province are exploiting with large quarrying depth, and the annual output could reach to tens of million cubic meters. The blasting frequency could be reached to hundreds of times, so the frequency is the major reason decreasing the cohesion of rock mass. Therefore, the surrounding area of blasting holes is broken, especially the area next to the final border where bench slope angle is not implemented as that of design stage, as well as the back break, also causes fractures on the bench slope, resulting in instability and unsafety due to falling rock. In this paper, the author also wants to introduce the pre blasting and the method to define blasting parameters to increase the stabilization of Slopes in Tan Cang quarry NO.1 in Vietnam.

Keywords: pre-splitting, limestone quarry, blasting parameters

\section{Introduction}

Pre blasting is a controlled blasting technique with applications in surface mining and underground mining. The main objectives of pre-blast in surface mining are preventing, controlling back-break; controlling excessive ground vibrations; and filtering the effects of explosive gases from production blasting. Pre blasting techniques are therefore more costly than re-designed production blasting because of the greater amount of drilling required. It is essential that drilling and charging be carefully supervised because the final result depends heavily on the time spent and accuracy of drilling (Nhu Van Bach et al.,1998, 2008), (Кутузов Б. Н. 1992), (William Hustrulid, 1999).

There have been many studies by scientists on pre blasting such as (Singh et al., 2014): Pre blasting created free surface has been shown to be successful in controlling back-break. The separating surface attenuates propagation of expanding gases to the remaining rock mass, i.e. the final walls (Adamson, 2013). Design of blast experiments is a method of defining the optimal pattern of pre-splitting (Xu and Peng, 2008; Dai, 2005; Ozer et al.,2013). Design of controlled blasting (pre-splitting) in Golegohar iron ore mine, Iran (S. R. Dindarloo et al.,2015).

Nowadays, construction material quarries in Dong Nai Province are exploiting with large quarrying depth, and the annual output could reach to tens of million cubic meters, the blasting scale according to explosive -used license is assigned from 2 to 3- explosive tones.

Blasting frequency could be reached to hundreds of times, so the frequency is the major reason decreasing the cohesion of rock mass. Blasting -induced wave propagating from the basting site could cause the oscillation and collapse of bench face, leading to unsafety risk and stripping- ratio increase, production cost and resource loss.
Meanwhile, accordance with reclamation project after exploitation accepted by the ministry of resources and environment or Dong Nai Province's committee, ultimate quarries is reclaimed to become lakes for aquaculture, tourism, etc. However, in exploiting operation, quarries only apply normal blasting methods (electric delay, non-electric delay). Therefore, the surrounding area of blasting holes is broken, especially the area next to the final border where bench slope angle is not implemented like that of the design stage, as well as the back break, also causes fractures on the bench slope, resulting in instability and unsafety due to falling rock. The lakes after extraction operation have not been reclaimed as a designed landscape with the aim of the permanent society benefits.

\section{Methods to reduce severe impacts on pit slope in blasting}

In hard rocks, blasting can create impact zone surrounding the explosive charge, including crushing, breaking, fracture and elastic deformation zone (Fig 1).

Blasting aims to reduce and eliminate the back-break zone along with the ground vibrations within the elastic deformation zone. The distance from the explosive charge to the outer boundary of this zone is deformation radius. (Nhu Van Bach et al., 2008), (Кутузов Б. Н. 1992).

I. The boundary between breaking and deformation zone

II. The outer boundary of the deformation zone

III. The shape of rock proportion within the braking zone after blasting

1. Explosive charge, 2. Crushing zone, 3. Breaking zone, 4. Fracture zone, 5. Deformation zone

Deformation radius of a single explosive charge can be determined as in Equation 1:

$$
\mathrm{r}=\alpha_{1} \alpha_{2} \sqrt[3]{\mathrm{Q} / \mathrm{C}_{0}, \mathrm{~m}}
$$




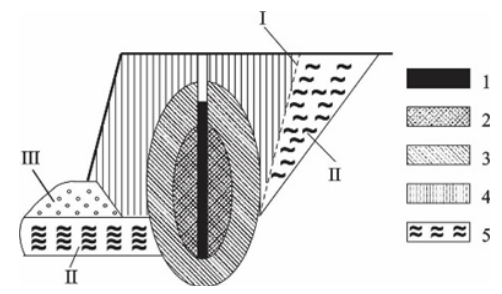

Fig. 1. Typical impacting zone of blasting within hard rocks

Rys. 1. Typowa strefa oddziaływania wybuchu w twardych skałach

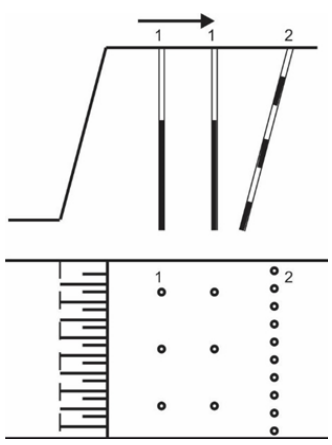

Fig. 2. Trim (Cushion) blasting method. 1. Production blast hole row; 2. Trim blast hole row Rys. 2. Strzałowa metoda Trim (Cushion)

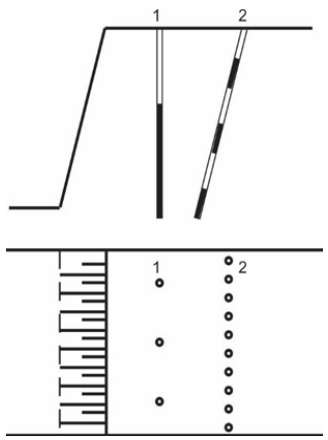

Fig. 3. Pre-splitting blasting method. 1. Production blast hole row; 2. Pre - splitting hole row Rys. 3. Metoda strzałowa wstępna

Where: $\alpha_{1}$ - factor considering the effect of free faces in cracking resistance of the rock mass, in which $\alpha_{1}=1$ if there are two free faces and $\alpha_{1}=1,2$ if there is one free face. $\alpha_{2}-$ the distance between study point and free face, in which $\alpha_{2}=1$ if the study point locates on or over the free face, $\alpha_{2}=2$ if the study point is inside the rock mass. $\mathrm{Q}$ - the weight of explosives, $\mathrm{kg} \mathrm{C}_{0}$ - index of fracture resistance of rock in blasting, $\mathrm{kg} / \mathrm{m}^{3}$.

The stability of pit slope is ensured by reducing the impact of blasting vibrations and eliminating the deformation zone within the rock mass (reducing the back break or deformation radius).

Some technological methods are recommended in the next sections, (Sandvik Tamrock Corp 1999), (Calvin J. Konya et al., 1990), (Carlos L.J., Emilio L.J. 1995).

\subsection{Using protection layers on the bench floor and slope}

The protection layers cover the rock mass that needs to be protected in blasting and does not contain the explosives. The width of the layers is calculated carefully to protect the rock mass.

\subsection{Reducing the explosive charge diameter}

This method aims to reduce the explosive charge diameter to narrow the deformation zone. Small blast holes are commonly used instead of the large ones. For instance, replacing blast holes with a diameter of $150 \mathrm{~mm}$ with that of $110 \mathrm{~mm}$ or $32 \mathrm{~mm}$ can reduce the deformation radius 1.7 to 4.7 times. Controlled blasting favours this method.

\subsection{Segmenting the explosive charge}

The explosive charge can be separated into some segments or decking. The gaps between the segments are filled with air or stemming materials. Deformation radius is considered as equivalent one in this method. This method is commonly applied in controlled blasting.

\subsection{Using low energy explosives}

Low energy explosives allow reducing the deformation radius. Specifically, the deformation radius can be lowered with a ratio of $\sqrt{ }\left(E_{c} E_{c}\right)$ and $\sqrt{ }\left(E_{E_{c}}\right)$ when detonating a dense and cylinder-shaped explosive charge and non-dense cylinder-shaped explosive charge, respectively (where: $\mathrm{E}$ is a spe- 


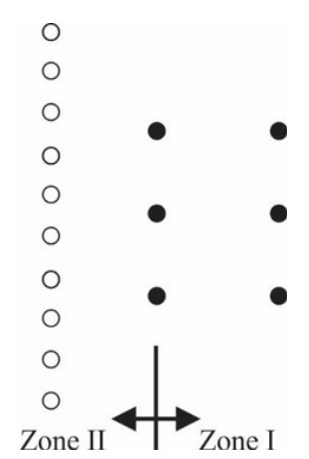

Fig. 4. Blasting pattern

Rys. 4. Schemat rozmieszczenia otworów

Tab. 1. Blasting parameters of production holes

Tab. 1. Parametry otworów strzałowych

\begin{tabular}{|c|l|c|c|c|}
\hline No & \multicolumn{1}{|c|}{ Parameters } & Unit & Symbol & Value \\
\hline 1 & Bench height & $\mathrm{m}$ & $\mathrm{h}$ & 10 \\
\hline 2 & Blast hole dip angle (in compared to the horizontal plane) & Degree & $\mathrm{a}$ & 75 \\
\hline 3 & Spacing & $\mathrm{m}$ & $\mathrm{a}$ & 3 \\
\hline 4 & Row spacing & $\mathrm{m}$ & $\mathrm{b}$ & 3 \\
\hline 5 & Burden at bench floor & $\mathrm{mm}$ & $\mathrm{W}$ & 3 \\
\hline 6 & Hole diameter & $\mathrm{m}$ & $\mathrm{d}_{\mathrm{k}}$ & 102 \\
\hline 7 & Drilling depth & $\mathrm{hole}$ & $\mathrm{N}$ & 11.4 \\
\hline 8 & Number of holes & $\mathrm{mm}$ & $\mathrm{d}_{\mathrm{z}}$ & 70 \\
\hline 9 & Charge diameter & $\mathrm{kg} / \mathrm{m}^{3}$ & $\mathrm{q}$ & 0.35 \\
\hline 10 & Powder factor & $\mathrm{kg}$ & $\mathrm{Q}$ & 28 \\
\hline 11 & Explosive quantity per hole & $\mathrm{m}$ & $\mathrm{L}_{\mathrm{t}}$ & 9.2 \\
\hline 12 & Total length of explosive charges (continuous charge) & $\mathrm{m}$ & $\mathrm{L}$ & 2,2 \\
\hline 13 & Stemming length & $\mathrm{kg}$ & $\mathrm{Q}$ & 840 \\
\hline 14 & Total quantity of explosive & Detonator & & 120 \\
\hline 15 & Number of non-electric detonators & Primer & & 60 \\
\hline 16 & Total number of primers, type 175g/primer & $\mathrm{m}^{3}$ & & 2.700 \\
\hline 17 & Total volume of blasted rocks (in mass) & & & \\
\hline
\end{tabular}

cific energy of the used explosive, $\mathrm{J} / \mathrm{Kg}$; and $\mathrm{E}_{\mathrm{c}}$ is a specific energy of the standard explosive, J/Kg).

\subsection{Using delay blasting}

This method ensures the individual impact of each explosive charge on the rock mass in blasting. There is no upper bound in choosing the delay time. However, the delay time needs to be chosen carefully to ensure the rock fragment requirements while guaranteeing the safety of ground vibrations and blasting pattern. blasting.

All these methods above can be applied in controlled

\section{Controlled blasting to ensure the slope stability at Tan Cang Quarry No.1}

3.1. Overview of terrain, mine geology, and mining parameters at the quarry

Mining situation

Tan Cang quarry No.1 is allowed to extract an area of 108.8 ha with an agreement of Dong Nai province. The deposit at the quarry was explored down to $-80 \mathrm{~m}$. The location of the quarry can be described as followings:

Next to Tan Cang No.6 in the north, two quarries made a connection at this side.

Next to Tan Cang No.7 in the south, two quarries made a connection at this side.

Next to a haulage ramp in the east, a protection pillar was left at this side.

Next to Buong river in the west and east-west, a protection pillar was left at this side.
At present, the quarry has been extracted over 22 ha in its centre and not reached the mining boundary. Also, the quarry has been exploiting to make a connection with Tan Cang quarry No.6 at the Northside.

\section{Geological characteristics}

The mining area mainly contains Andesite rocks which are hard and relatively homogeneous, within Binh Long formation. The physical properties of this rock are as followings:
- Volumetric mass:
$2,77 \mathrm{~g} / \mathrm{cm}^{3}$
- Density $(\Delta)$ :
- Internal friction angle (degree):
$2,86 \mathrm{~g} / \mathrm{cm}^{3}$
$43^{\circ} 05^{\prime}$
- Cohesion force $(\mathrm{C})$
$320,69 \mathrm{kG} / \mathrm{cm}^{2}$
- Average dry compressive strength:
$1483 \mathrm{kG} / \mathrm{cm}^{2}$

- Average saturated compressive strength: $1160 \mathrm{kG} / \mathrm{cm}^{2}$

The geological conditions of this rock layer are stable.

Mining and final pit slope parameters

*Mining parameters:

- Mining bench height:

$$
\begin{aligned}
H & =10 \mathrm{~m} \\
\propto & =80^{\circ} \\
A & =13,5 \mathrm{~m}
\end{aligned}
$$

- Bench slope angle:

- Mining width:

* Final pit slope parameters:

- Final bench height:

$\mathrm{Hkt}=20 \mathrm{~m}$

- Final bench slope angle:

$\propto \mathrm{kt}=75^{\circ}$

- Protection berm:

$\mathrm{Bv}=7 \mathrm{~m}$

\subsection{Selection of controlled blasting method for Tan Cang} quarry No.1 
Tab. 2. Blasting parameters of pre-splitting holes using the equations above

Tab. 2. Parametry otworów strzałowych z etapu wstępnego

\begin{tabular}{|c|c|c|c|c|}
\hline No & Parameters & Unit & Symbol & Value \\
\hline 1 & Bench height & $\mathrm{m}$ & $\mathrm{h}$ & 10 \\
\hline 2 & $\begin{array}{l}\text { Blast hole dip angle } \\
\text { (in compared to the horizontal plane) }\end{array}$ & degree & a & 75 \\
\hline 3 & Spacing & $\mathrm{m}$ & $\mathrm{a}$ & 1.5 \\
\hline 4 & Distance from the pre-splitting row to the production row & $\mathrm{m}$ & $\mathrm{b}$ & 1.5 \\
\hline 5 & Hole diameter & $\mathrm{mm}$ & $\mathrm{d}_{\mathrm{k}}$ & 102 \\
\hline 6 & Hole depth & $\mathrm{m}$ & $\mathrm{L}_{\mathrm{k}}$ & 11.4 \\
\hline 7 & $\begin{array}{l}\text { Total length of explosive } \\
\text { charges ( } 3 \text { decks) }\end{array}$ & $\mathrm{m}$ & $\mathrm{Lt}$ & 7.2 \\
\hline 8 & Length of the primary stem & $\mathrm{m}$ & $\mathrm{L}_{b c}$ & 2.2 \\
\hline 9 & Decking length (2 decks) & $\mathrm{m}$ & $\mathrm{Lpd}_{\mathrm{pd}}$ & 1 \\
\hline 10 & Number of pre-splitting holes per row & hole & $\mathrm{N}$ & 9 \\
\hline 11 & Total length of pre-splitting holes & $\mathrm{m}$ & & 102.6 \\
\hline 12 & Charge diameter & $\mathrm{mm}$ & $\mathrm{d}_{\mathrm{z}}$ & 60 \\
\hline 13 & Explosive loading density & $\mathrm{kg} / \mathrm{m}$ & $\otimes$ & 0.8 \\
\hline 14 & $\begin{array}{l}\text { Quantity of explosive per } \\
\text { pre-splitting hole }\end{array}$ & $\mathrm{kg}$ & $\mathrm{Q}_{1}$ & 8 \\
\hline 15 & Total quantity of explosives & $\mathrm{kg}$ & $\otimes \mathrm{Q}$ & 72 \\
\hline 16 & $\begin{array}{l}\text { Total number of non-electric } \\
\text { detonators (No.1) }\end{array}$ & detonator & & 36 \\
\hline 17 & $\begin{array}{l}\text { Total number of primmer, } \\
\text { type } 175 \mathrm{~g} / \text { primer }\end{array}$ & primer & & 36 \\
\hline
\end{tabular}
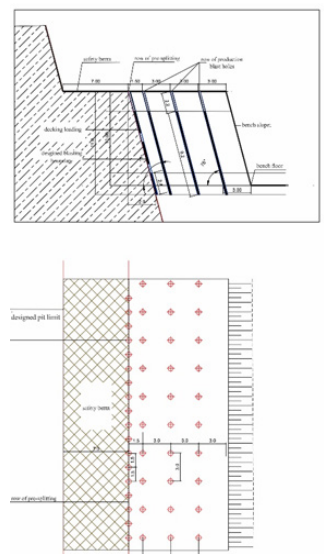

Fig. 5. Pattern of pre-splitting blast holes on the bench

Rys. 5. Schemat rozmieszczenia otworów strzałowych obrysowych z etapu wstępnego

Two controlled blasting methods were chosen for this research, (Nhu Van Bach et al.,1998, 2008), (Кутузов Б. Н. 1992) (Sandvik Tamrock Corp 1999), (Calvin J. Konya et al., 1990), (Carlos L.J., Emilio L.J. 1995), (William Hustrulid, 1999).

\section{Trim (Cushion) blasting}

This method breaks the rock mass sequentially from the outside to the required excavation boundary (trim holes are fired after production holes) (Fig. 2).

Advantages and disadvantages of this method are summarized below:

* Advantages:

- Able to use dipping and trim blast holes create the designed excavation boundary.

- Easy to control blasting, reducing flying rocks if initiating sequentially from the outside to inside.

* Disadvantages:

- In drilling:

+ Require navigating blast holes correctively on the plan, cross-sections, and the field.

+ Increase the drilling length if the blast holes are dip.

+ Increase the number of blast holes due to the decrease of distance between trim blast holes.

- In blasting:

+ Result in back-break, unstable pit slope, and hanging rocks due to the transmission of stress waves from the outside.

\subsection{Pre-splitting blasting method}

Like trim blasting involves a single row of blast holes along the specified excavation boundary. The pre-splitting holes are located closely and fired prior to the production holes (Fig. 3).

* Advantages:

- high chance to create a designed boundary, smooth bench slope and less hanging rocks. In the explosion process, a maximum stress wave is developed along the connection line between two explosive charges, resulting in a separate line within the rock mass which follows the designed boundary and creates a crack shielding the back breaks from the production holes.

* Disadvantages:

- In drilling: similar to trim blasting method.

- In blasting: controlling the pre-splitting holes is quite complicated and can generate ground vibration and flying rocks. Nevertheless, charging a small amount of explosive in these holes can solve the problems. 


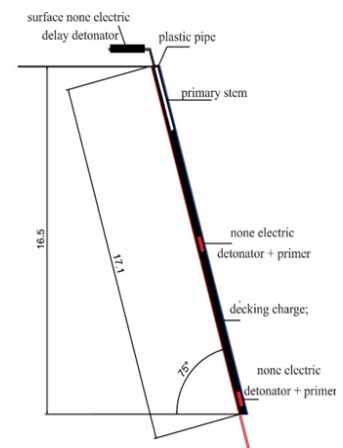

Fig. 6. The structure of explosive charge for Production holes Rys. 6. Struktura ładowania wybuchowego dla otworów produkcyjnych (włomowych)

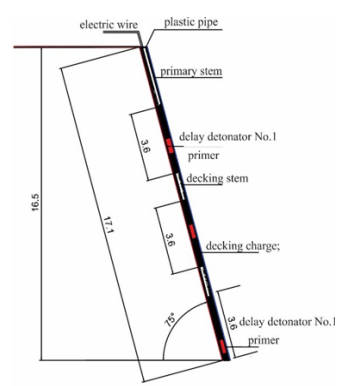

Fig. 7. The structure of explosive charge for the pre-splitting holes Rys. 7. Struktura ładowania wybuchowego dla otworów obrysowych

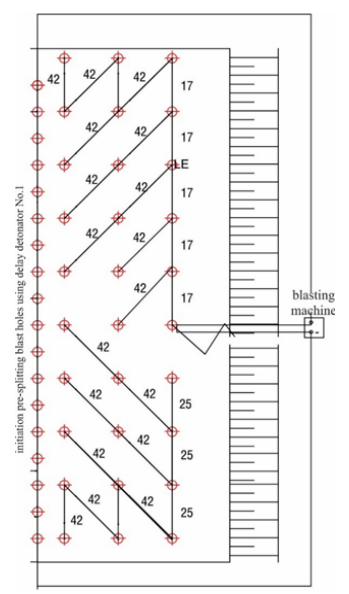

Fig. 8. Initiation sequence

Rys. 8. Schemat łączenia zapalników

Based on the analysis above, pre-splitting blasting method was chosen for Tan Cang quarry No.1 with the aims of improving the efficiency in blasting operations, including creating a designed boundary, increasing slope stability, reducing hanging rocks, ensure working safety conditions, and protecting the surrounding environment.

\section{Determination of pre-splitting blasting parameters for Tan Cang quarry No. 1}

With the pre-splitting blasting method selected above, the hole pattern is divided into two areas, as shown in Figure 4. The area I includes the production holes. In this case, the quarry used the holes of $102 \mathrm{~mm}$ in diameter. Blasting parameters of production holes in the area I were chosen according to the current blasting report, as shown in Table 1.
Area II includes pre-splitting holes with the diameter dlk $=102 \mathrm{~mm}$. Blasting parameters for these holes were determined as followings:

\subsection{Explosive type}

Currently, most quarries in the South East of Vietnam use ANFO, AD1, NT-13, NT-31. In this research, we selected NT-13, EE-31 or ANFO based on their parameters for the pre-splitting holes. Generally, these explosives have a medium-strength, low charge density, easy to use and diverse in diameters such as $\Phi 60$, Ф80, 990 for various drilling holes.

\subsection{Explosive diameter and density}

Explosives, which are packed in cylindrical cartridges or porous pilled forms, are preferred to create a space between 


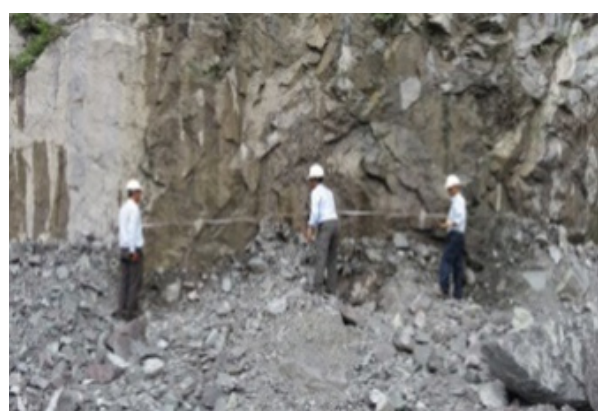

Fig. 9. Geological survey

Rys. 9. Badanie geologiczne

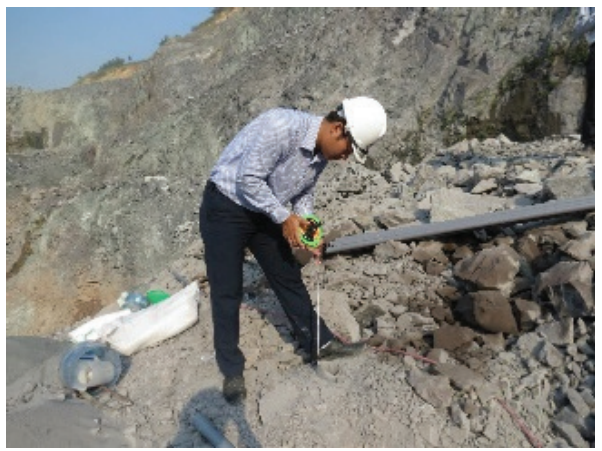

(a)

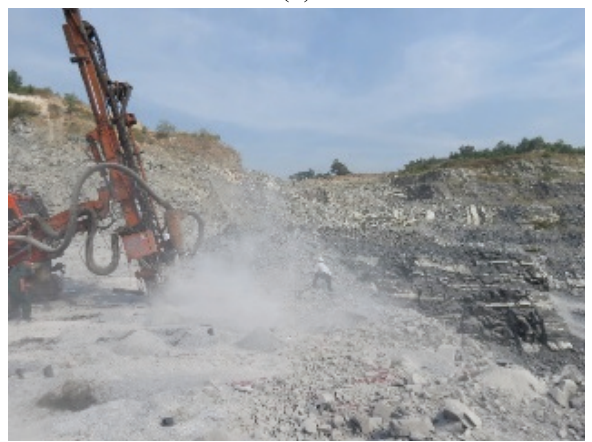

(b)

Fig. 10. Drilling operation at the blasting location Rys. 10. Esperymentalne prace strzelnicze

the explosive and blast hole wall. In practice, one can apply an experimental equation to calculate the explosive's diameter, as followings, (Nhu Van Bach et al.,1998, 2008), (Sandvik Tamrock Corp 1999), (Calvin J. Konya et al., 1990):

$$
\mathrm{d}_{\mathrm{t}}=(0.2 \div 1.0) \mathrm{d}_{\mathrm{k}}
$$

The value between 0.2 and 1.0 can be chosen according to the rule of small value for soft rocks and a large value for hard rocks. Besides, decking charging method was chosen to narrow the deformation continues.

* Explosive density

The amount of explosive per one meter within a pre-splitting hole can be calculated based on loading density and pre-splitting hole diameter, as in the Equation below:

$$
\mathrm{P}=100 \cdot \frac{\Pi \cdot \mathrm{d}_{\mathrm{k}}^{2}}{4} \cdot \Delta \mathrm{k}=78,5 \cdot \mathrm{d}_{\mathrm{k}}^{2} \cdot \Delta \cdot \mathrm{k}, \mathrm{kg} / \mathrm{m}
$$

where: $\mathrm{d}_{\mathrm{k}}$ - diameter of a pre-splitting hole, $\mathrm{mm} ; \Delta$ - loading density, $\mathrm{g} / \mathrm{cm}^{3}$ (ANFO: $\Delta=0.9 \mathrm{~g} / \mathrm{cm} 3$; emulsions EE31 or EE13: $\left.\Delta=1.0 \mathrm{~g} / \mathrm{cm}^{3}\right) ; \mathrm{k}$ - filling ratio of the explosive $(\mathrm{k}=0.85)$.

\subsection{Spacing between pre-splitting holes}

The spacing between pre-splitting holes can be determined as followings, (Nhu Van Bach et al.,1998, 2008), (Кутузов Б. Н. 1992):

$$
a=22 \cdot d_{z} \cdot k_{z} \cdot k_{y}, m
$$

Where: $\mathrm{d}_{\mathrm{z}}$ - diameter of a pre-splitting hole, $\mathrm{mm}$; $\mathrm{kz}$ - compress ratio, $\mathrm{k}_{\mathrm{z}}=0.25$ in the case of full compression (ramp digging); $\mathrm{k}_{\mathrm{z}}=1.0$ if there are no less than four rows of blast holes on a bench; $\mathrm{kz}=1.1$ if there are less than four rows of blast holes on a bench; $\mathrm{k}_{\mathrm{y}}$ - ratios considering the geological condition; $\mathrm{k}_{\mathrm{y}}=1.0$ if there is no any fracture; $k_{y}=0.9$ and 0.85 if the angles of the fracture face and boundary face are 900 and $200 \div 700$, respectively; $\mathrm{k}_{\mathrm{y}}=1.15$ if the fracture face and boundary face are matching.

In practice, the spacing between pre-splitting holes can be determined as followings: 


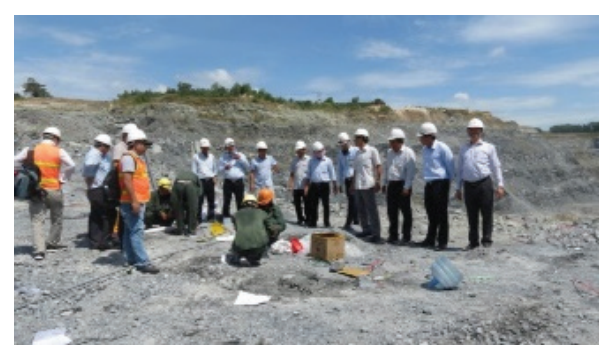

(a)

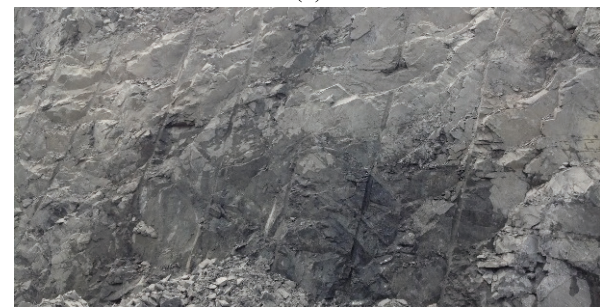

(b)

Fig. 11. Blasting implementation and results Rys. 11. Eksperymentalne prace terenowe

$$
a=(12 \div 15) d_{k}, m
$$

Stemming length of pre-splitting holes should be $2 \div 4 \mathrm{~m}$. Also, these holes are drilled with an identical length, and no sub-drilling is required.

The distance from the pre-splitting holes and production holes equals half of the distance between the production holes.

\subsection{Powder factor}

The pre-splitting holes aim to extract the rock mass in order to create a smooth face. Hence, their powder factor is defined as the amount of explosive used to create a square meter of a smooth face, as determined in Equation 6, (Nhu Van Bach et al.,1998, 2008), (Кутузов Б. Н. 1992), (Sandvik Tamrock Corp 1999), (Calvin J. Konya et al., 1990):

$$
\mathrm{q}_{\mathrm{m}}=\frac{\Sigma \mathrm{Q}}{\Sigma \mathrm{S}} ; \mathrm{kg} / \mathrm{m}^{2}
$$

Where: $\Sigma \mathrm{Q}$ - the total amount of explosives, $\mathrm{kg} ; \Sigma \mathrm{S}$ - total area of smooth face, $\mathrm{m}^{2}$.

Equation 7 can be used to determine the powder factor for each hole.

$$
\mathrm{q}_{\mathrm{m}}=\mathrm{Q} /(\mathrm{a} . \mathrm{l}) ; \mathrm{kg} / \mathrm{m}^{2}
$$

Where: Q - total amount of explosives for each pre-splitting hole, kg; a - spacing between pre-splitting holes, $\mathrm{m}$; 1 pre-splitting hole depth, $\mathrm{m}$.

Consequently, $\mathrm{qm}$ is then deployed to calculate the amount of explosive for a pre-splitting hole, as shown in Equation 8.

$$
\mathrm{Q}=\text { qm.a.l, } \mathrm{kg}
$$

One can use the experimental values below to determine the powder factor of pre-splitting holes [10].
+ Hard blasting:
$0.6 \div 0.9 \mathrm{~kg} / \mathrm{m}^{2}$
+ Average blasting: $0.3 \div 0.6 \mathrm{~kg} / \mathrm{m}^{2}$
+ Easy blasting:
$0.2 \div 0.3 \mathrm{~kg} / \mathrm{m}^{2}$

\subsection{Structure of the explosive charge and initiation sequence} Structure of the explosive charge plays an essential role in pre-splitting blasting. It is necessary to account for the structure of the explosive charge to minimize the size of the deformation zone. Charge diameter contributes significantly to it. In practice, there are some methods such as creating a gap between the explosive charge; loading the explosive close to the zone required to break, and the remaining zone is sand; sticking explosive charges on a long wooden pole and loading this pole into the pre-splitting hole with its wooden part contacting with the required smooth face, (Nhu Van Bach et al.,1998, 2008), (Calvin J. Konya et al., 1990), Sandvik Tamrock Corp (1999).

Each pre-splitting blast hole contains $8 \mathrm{~kg}$ (equals $25 \%$ the amount of explosive in the production holes). Decking loading is used with pieces of rock. The diameter of the charge was $\mathrm{d}=60 \mathrm{~mm}$. The pre-splitting blast holes are initiated using delay non-electric detonators No.1.

Initiation sequence: the row of pre-splitting blast holes is fired first with the delaying time of $50 \div 75 \mathrm{~ms}$ compared with the production blast holes in order to create an initial crack which is a shield to prevent the stress wave transmitting from the production blast holes. Figure 5, 6, 7, 8 presents pattern of pre-splitting blast holes on bench, the structure of explosive charge for the pre-splitting holes and the initiation sequence in this research.

\section{Experimental results \\ 5.1. Geological survey}

A geological survey was implemented on the field to adjust the drilling and blasting parameters into practical conditions. Figure 8 illustrates the geological survey implemented in Tan Cang quarry No.1.

\subsection{Drilling}

It is crucial to keep drilling in the right direction and location. Tan Cang quarry No.1 has deployed the hydraulic rotary drill machine TAMROCK with a diameter of $d=102 \mathrm{~mm}$. Figure 10 describes how drilling was fulfilled at the blasting location. 


\subsection{Blasting implementation and results}

The experiments created a relative smooth bench floor, no back-break, and ensures the bench slope of $70^{\circ} \div 75^{\circ}$ according to the design. These results contribute to the safety in operations at the quarry significantly. Figure 10 shows the implementation of the blasting experiments at the quarry.

\section{Conclusion}

From the results, we propose a full blasting parameter for Tan Cang quarry No.1 which is also possible to apply in raw material quarries in the South East of Vietnam to reduce the harmful effects of blasting in slope stability and surrounding constructions.
Controlled blasting is necessary for deep open-pit mines and quarries, especially in the locations close to pit limits, landslide areas, making possible conditions to mine deeper, and recovering the mineral resource effectively.

\section{Acknowledgements}

The authors would like to thank Bien Hoa Building Materials Production and Construction Company and Nam Bo Mining Chemical Industry Company - MICCO, Baria - Vungtau, Vietnam provided documents and coordinated to help us in the experimental blasting process at Tan Cang quarry No.1 to complete this paper.

\section{Literature - References}

1. Nguyen Dinh Au, Nhu Van Bach (1998), Blasting of rock, Vietnam Education Publishing House limited Company.

2. Nhu Van Bach (2008), Increase the blasting effect in mining, Traffic and Transportation" Publisher, Hanoi.

3. William Hustrulid (1999), Blasting principles for Open Pit Mining, Colorado School of Mines, USA.

4. Sandvik Tamrock Corp (1999), Rock Excavation Handbook.

5. Кутузов Б. Н. (1992), Разрушение горных пород взрывом, Изд. МГИ., Москва.

6. S. R. Dindarloo, N.-A. Askarnejad, and M. Ataei (2015), Design of controlled blasting (pre-splitting) in Golegohar iron ore mine, Iran ansactions of the Institution of Mining and Metallurgy, Section A: Mining Technology 124(1):64-68.

7. Kazem Oraee, Ali Mozafari, Arash Goodazi, and Nikzad Oraee-Mirzamani (2006), Final wall stability in metal open pit mines using presplit blasting, University of Stirling Stirling, United Kingdom, 23 World Mining Congress, At Montreal, Canada.

8. Carlos L.J., Emilio L.J. (1995), Drilling and Blasting of Rocks, Geomining Technological Institute of Spain, Spain.

9. Sandvik Tamrock Corp (1999), Rock excavation handbook.

10. Calvin J. Konya, Edward J. Walter (1990), Surface Blast design, Englewood Cliffs, N. J.: Prentice-Hall.

\section{Projekt techniki strzelniczej $w$ kamieniołomie Nr 1 w Tan Cang $n r 1 w$ Wietnamie}

Obecnie kamieniołom litych surowców skalnych w prowincji Dong Nai prowadzi eksploatację na dużej głębokośc. Roczne wydobycie materiałów budowlanych dochodzi do kilkudziesięciu milionów metrów sześciennych. Duża ilość wybuchów powtarzających się rocznie jest główna przyczyna osłabienia więzi skalnej $w$ masie wraz z rozprzestrzenianiem sie fal sejsmicznych $z$ wybuchów powoduja więc drgania i niszczenie warstwy, osuwisko kopalniane i różne deformacje nieciagłe. W artykule, przedstawiono metody wyznaczenia granicznych parametrów robót strzałowych oraz diagram wybuchów w celu zwiększenia stabilności zbocza w kamieniołomie nr 1 -Tan Cang 1 w Wietnamie.

Słowa kluczowe: techniki strzelnicze, kamieniołom wapienia, parametry wybuchu 